\title{
The Role of Personal Learning Orientations and Goals in Students' Application of Information Skills in Malaysia
}

\author{
Aidah Abdul Karim, Parilah M. Shah, Fariza Khalid, Mazalah Ahmad, Rosseni Din \\ Faculty of Education, Universiti Kebangsaan Malaysia, UKM Bangi, Selangor, Malaysia \\ Email: eda@ukm.edu.my
}

Received 9 September 2015; accepted 27 October 2015; published 30 October 2015

Copyright (C) 2015 by authors and Scientific Research Publishing Inc.

This work is licensed under the Creative Commons Attribution International License (CC BY). http://creativecommons.org/licenses/by/4.0/

(C) (i) Open Access

\begin{abstract}
Information skills assist students to develop and apply new understanding in their field of study, and thus hold a key to knowledge building process in higher learning. A qualitative study was conducted to explore the role of personal factors in the application of information skills among university students in Malaysia. The study was conducted in a Malaysian public university and the participants were 31 lecturers, librarians and students who were involved in student information skills programs run by the university library. The study observed the programs and examined the programs' learning and teaching materials and interviewed the lecturers, librarians and students. The study found that personal learning orientations and goals influenced students' application of information skills across their university learning. The study suggested that in order to assist students to use information skills throughout their university learning, universities must help students to align their personal learning orientations toward university learning, as well as to help student to develop long term personal learning goals.
\end{abstract}

\section{Keywords}

Information Skills, Higher Learning, Learning Orientations, Learning Goals, Malaysia

\section{Introduction}

The term "information skills" is closely related to "information literacy", a term which was first introduced by Paul G. Zurowski in 1974 when he made a recommendation to the United States to develop a national programme that could assist the development of information literate workforces (Bawden, 2001; Bruce, 1997). Zurowski defined that the information literate workforces were those who “...had learned to use a wide range of 
information sources in order to solve problems at work and in his or her daily life” (as cited in Kerns, 2002: p. 351). Later, using the term "information skills", Marland (1981), Irving (1985) and Herring (1996) introduced the information literacy concept in the United Kingdom as a set of learning skills that assisted school children to use, transform, re-package, and communicate information.

A functional relationship between information literacy and information skills is given by The Chartered Institute of Library and Information Professionals that stated information literacy is an understanding of: "A need for information, the resources available for finding information, the need to evaluate results, how to work with or exploit results, ethics and responsibility of use, how to communicate or share your findings, and how to manage your findings" (Chartered Institute of Library and Information Professionals, 2012: p. 1), which requires individuals to master several information-related skills such as abilities to identify the need for information and resources available, and to find, evaluate, use or exploit, communicate and manage information in an ethical and responsible manner. Presently information skills are being discussed beyond school learning; they have been identified as pre-requisite skills for higher and lifelong learning (Bawdeen, 2001; Bundy, 2004; Bruce \& Lupton, 2006; Catts \& Lau, 2008).

In the context of Malaysian higher education, information skills are identified as information problem solving skills that are fundamental to facilitate the development of university students who are able to apply critical and innovative thinking in their field of study. The introduction of the Malaysian Qualification Framework (Malaysian Qualifications Agency, 2007) into the national education system in late 2006 highlighted university students' acquisition of information skills in Malaysia when the framework identified "information skills" element as part of student learning outcome in higher education. Information skills programs have been introduced to Malaysian public universities to assist students to attain the learning outcomes and simultaneously to transform students into knowledge workers (Chan, 2003; Edzan \& Mohd Saad, 2005; Mohd Saad \& Awang Ngah, 2002) who are characterized by their ability to "acquire, apply, synthesize and create knowledge" (Economic Planning Unit, 2001: p. 112).

Today, the development of The Education Transformation Plan 2015-2025 for Higher Education (Ministry of Education Malaysia, 2015) has reinforced further the acquisition and demonstration of information skills in higher learning in facilitating the development of university graduates who have inquisitive mind and innovative minds, and are able to apply and generate knowledge to solve problems. The new education plan also implies that information skills learning activities are no longer confined within the library walls, i.e. via student information skills programs, but must be integrated in classroom learning.

Literature has identified various personal factors that influence students' acquisition and application of information skills in their learning process. Among others, Neely (2000) found that students' engagement in information-related behaviours and thinking is influenced by their experience and exposure to library or other information environments, while Gorman \& Dorner (2006), Grassian \& Kaplowitz (2001) and Lantz \& Brage (2006) argued that students' daily tasks, needs, and interests influence students' usage of information skills. Some researchers also highlighted that students' inability to perform certain information behaviours may hinder their application of information skills. Specifically, Badger \& Roberts (2005), and Hepworth \& Wema (2006) found that students' inability to obtain information and its sources independently from classroom teachers affected their evaluation and use of information; suggesting that information skills are a set of interrelated and sequential information-related behaviours and thinking processes. Kilic-Cakmak (2010) also suggested that personal learning strategies, critical thinking and control belief contribute toward students' perceptions of their level of information skills. Similar to Fitzgerald (1999), Kilic-Cakmak (2010) stated that the use of metacognitive strategies would enable students to define their information needs; develop proper searching strategies to access information, evaluate and interpret the information; and evaluate their learning outcomes and process, while the use of critical thinking helps students to organize and manage their learning processes. Additionally, an increase in students' control belief will result in an improvement in students' ability to develop searching strategies, access to information and communicating information (Kilic-Cakmak, 2010). Brown (2005) found further a correlation between students' academic self-concept and information skills efficacy. Such a finding was expected because students who have a positive attitude towards learning are more likely to engage in knowledge-construction processes that involved the application of information skills in comparison to students who have less or negative attitude towards learning.

The literature also highlighted the fact that students' philosophy about the nature of knowledge and sources of knowledge influence their application of information skills. For example, Bruce, Edwards, \& Lupton (2006) 
found that students have arrays of views about learning; ranging from the acquisition and memorising of facts, understanding and interpreting information, to changing as a person. The diverse epistemology about learning process and sources provides students with a range of unique and individualized understanding of their information needs, which in turn guides their information search, collection, management, analysis, and synthesis (Badger \& Roberts, 2005; Bruce et al., 2006; Bruce, 2005; Gorman \& Dorner, 2006; Grassian \& Kaplowitz, 2001). For instance, Fitzgerald (2005) argued that the way students view knowledge either absolute or fluid influences their ways of searching information and determining the credibility of information taken from multiple sources. Jamali (2008) added that students' convenience is another factor that influences students' information behaviours. Specifically Jamali (2008) found that students' beliefs on the value of online information sources are primarily based on easy accessibility of the sources. Jamali (2008) further found that there is a relationship between perceived accessibility and the selection of particular information sources, which he explained using Zipf's Least Effort Theory. The theory posits that animals, people, and even well-designed machines will naturally choose the path of least resistance or effort in order to accomplish their goals.

Lastly, Julien \& Boon (2002) found that aspects of personal situations and practices such as the nature of their information-related activities, time constraints, motivation, physical location of students and information sources, and the purpose of satisfying information needs also affected students' activities when searching, accessing, and evaluating information. They discovered that individuals are more likely to use information for decision-making when motivation was internal rather than external and mixed, and use more sources in an open or undetermined timeframe. They also discovered that individuals also use more sources of information when the information task is of a personal nature; and the most useful sources were chosen onsite; indicating the use of familiar sources at hand rather than other sources available in the field.

There are a few studies that examined students' information skills in higher education institutions in Malaysia (e.g. Abdullah et al., 2006; Edzan, 2007; Karim et al., 2004, 2014). Most of these studies attempted to quantify university students' level of information skills, and correlate the information skills level to the students' personal contexts - ethnics, and academic programs and academic achievement. While these findings were helpful to describe and hypothesize students' perceived level of information skills in the light of the students' personal contexts, these studies are insufficient to explain the role of personal contexts in the students' acquisition and application of information skills across their classroom learning. While a few studies have investigated dual perspectives of higher education educators-librarians (e.g., Boon et al., 2007; Bruce, 1997; Doyle, 1992), and a single perspective of students (e.g. Lupton, 2003; Maybee, 2007) with regard to students' learning of information skills, it was still uncommon to investigate the learning using trio perspectives of teachers, librarians and students. It is expected that the concurrent and triangulated perspectives of lecturers, librarians and students would lead to more comprehensive understanding of students' acquisition and usage of information skills in higher education.

\section{Purpose of the Study}

The purpose of the study is to explore the role of students' personal contexts in the acquisition and application of information skills as experienced and perceived by university teachers, librarians and students who were involved in information skills programs in Malaysian higher education. This study is vital for opening another door for researchers and practitioners to deepen understanding and improve practice in assisting students to acquire and employ information skills in knowledge building process in higher education. This study also corresponds well with the Malaysian Education Plan 2015-2025 (Higher Education) that requires higher education students to be developed in terms of their ability to appreciate multiple views, think critically and innovatively, solve problems and demonstrate entrepreneurships (Ministry of Education Malaysia, 2015) which could be done by helping the institutions to identify the role of students' personal contexts in the acquisition and application of information skills in higher learning.

\section{Methodology}

This study employed a qualitative research approach that is characterized by real and information rich cases, and flexible and emergent in the nature (Bogdan \& Biklen, 2007; Merriam, 2009). Qualitative study requires researchers to immerse in the phenomenon under study at personal level, use multiple perspectives to understand the phenomenon and locate the findings in the social, historical and temporal context where the phenomenon is being studied (Patton, 2002). Although qualitative research approach has been widely employed to investigate 
student learning of information skills in higher education using a single student perspective (e.g. Lupton, 2003; Maybee, 2007), and duo perspective of higher education teachers and librarians (e.g., Boon et al., 2007; Bruce, 1997; Doyle, 1992), the approach is not yet commonly used to triangulate trio perspectives of higher education teachers, librarians and students in students' learning of information skills.

Following the qualitative research approach, this study was conducted in a Malaysian university that offered student information skills programs and allowed an entry to collect data of the study. Working closely with librarians in the university's academic library, the study selected and observed five student information skills programs that involved teachers, librarians and students from various undergraduate and postgraduate academic programs. The data-collection phase began with observation of five information skills programs because the observation enabled the study to access direct and real data (Robson, 2002) related to students' application of information skills. Observation was employed in this study as "an initial phase where other methods will take over" (Gillham, 2000: p. 48) which provided the study with an open and unbiased window to identify various aspects of the students' application of information skills that would be investigated further during the next stage of data collection (Silverman, 2006). The study had focused the observation on the programs' content, teaching and learning activities and materials, and interactions took place between and among librarians and students during the programs.

The study examined further teaching and learning resources of the observed information skills programs during the second phase of the study's data collection. Among the resources examined by the study were Powerpoint slide presentations; Library of Congress Subject Heading and library handbook and pamphlets used by librarians; student information skills assignments where available the library booklet; web page, cataloging system, and internal and internal online databases; and an evaluation form for information skills programs. Examining these materials helped the study to gain a deeper understanding of the aims, components and running of the observed programs in relation to students' application of information skills. Based on analysis of these resources, the study found several broad themes which had been incorporated into the development of the study interview protocols, i.e., nature, learning outcomes, and learning activities for students' application of information skills. The study also examined completed student information skills assignments and grades that were shown during interviews with two librarians, classroom syllabus and completed classroom assignments which were shown during an interview with one of the lecturers, university working documents related to the foundation and implementation of outcome-based learning in the university and government documents related to the Malaysian Qualification Framework and Research University that had been mentioned during interviews with two lecturers.

Lastly the study conducted semi-structured interviews with 31 lecturers, librarians, and students involved in the observed information skills programs and willing to participate in the study. Tables 1-3 show profiles of lecturer, librarians and students participated in the study respectively. For the purpose of research ethics, the study used pseudonyms to protect the participants' privacy and confidentiality. Specifically, the study conducted four individual and one paired semi-structured interviews with the four librarians; five individual semi-structured interviews with the five teachers; and eleven individual, four paired and one trio semi-structured interviews with 22 students. The study employed semi-structured interviews because the interviews could help the study to identify, acknowledge and incorporate aspects of students' application of information skills that were

Table 1. Profile of lecturer participants.

\begin{tabular}{|c|c|c|c|c|c|c|}
\hline No & Name & Gender & Age & Position & $\begin{array}{l}\text { Knowledge } \\
\text { Discipline }\end{array}$ & Courses \\
\hline 1 & Ana & Female & $50-55$ & $\begin{array}{l}\text { Associate } \\
\text { Professor }\end{array}$ & Pure science & Academic writing for undergraduate students \\
\hline 2 & Nora & Female & $40-45$ & $\begin{array}{l}\text { Senior } \\
\text { lecturer }\end{array}$ & Social science & Information technology for postgraduate students \\
\hline 3 & Onn & Male & $56-60$ & Professor & Pure science & Academic writing for undergraduate students \\
\hline 4 & Sam & Male & $45-50$ & $\begin{array}{l}\text { Associate } \\
\text { Professor }\end{array}$ & Social science & $\begin{array}{l}\text { Research methods for undergraduate and } \\
\text { postgraduate students }\end{array}$ \\
\hline 5 & Wani & Female & $35-40$ & $\begin{array}{l}\text { Associate } \\
\text { Professor }\end{array}$ & Pure science & Academic writing for undergraduate students \\
\hline
\end{tabular}


Table 2. Profile of librarian participants.

\begin{tabular}{|c|c|c|c|c|c|}
\hline No & Name & Gender & Age & Qualification & Position \\
\hline 1 & Azi & Female & $35-40$ & $\begin{array}{l}\text { Pure science degree and diploma in } \\
\text { Library and Information Science }\end{array}$ & Librarian \\
\hline 2 & Lia & Female & $40-45$ & $\begin{array}{l}\text { Social science degree and diploma in } \\
\text { Library and Information Science }\end{array}$ & $\begin{array}{l}\text { Librarian and library } \\
\text { management position }\end{array}$ \\
\hline 3 & Mia & Female & $35-40$ & $\begin{array}{l}\text { Degree and master in Library and } \\
\text { Information Science }\end{array}$ & $\begin{array}{l}\text { Librarian and library } \\
\text { management position }\end{array}$ \\
\hline 4 & Sal & Female & $30-35$ & Degree in Library and Information Science & Librarian \\
\hline
\end{tabular}

Table 3. Profile of student participants.

\begin{tabular}{|c|c|c|c|c|c|c|}
\hline No & Name & Gender & Age & Education program & Knowledge Discipline & Courses \\
\hline 1 & Cheng & Male & $20-25$ & Bachelor & Pure science & Academic writing \\
\hline 2 & Feza & Female & $20-25$ & Bachelor & Pure science & Academic writing \\
\hline 3 & Fazil & Male & $20-25$ & Bachelor & Pure science & Academic writing \\
\hline 4 & Hani & Female & $20-25$ & Bachelor & Pure science & Academic writing \\
\hline 5 & Kan & Female & $20-25$ & Bachelor & Pure science & Academic writing \\
\hline 6 & Lily & Female & $20-25$ & Bachelor & Pure science & Academic writing \\
\hline 7 & Leng & Female & $20-25$ & Bachelor & Pure science & Academic writing \\
\hline 8 & Razak & Male & $20-25$ & Bachelor & Pure science & Academic writing \\
\hline 9 & Amy & Female & $20-25$ & Bachelor & Social science & Research methods \\
\hline 10 & Kam & Female & $20-25$ & Bachelor & Social science & Research methods \\
\hline 11 & Kay & Female & $20-25$ & Bachelor & Social science & Research methods \\
\hline 12 & Muz & Male & $20-25$ & Bachelor & Social science & Research methods \\
\hline 13 & Raz & Male & $20-25$ & Bachelor & Social science & Research methods \\
\hline 14 & Awatif & Female & $26-30$ & Master & Social science & Information technology \\
\hline 15 & Joe & Male & $26-30$ & Master & Social science & Information technology \\
\hline 16 & Karin & Female & $26-30$ & Master & Social science & Information technology \\
\hline 17 & Wina & Female & $26-30$ & Master & Social science & Information technology \\
\hline 18 & Jannah & Female & $36-40$ & Master & Social science & Research methods \\
\hline 19 & Maya & Female & $26-30$ & Master & Social science & Research methods \\
\hline 20 & Naim & Female & $30-35$ & Master & Social science & Research methods \\
\hline 21 & Nori & Female & $36-40$ & Master & Social science & Research methods \\
\hline
\end{tabular}

unique to the participants' experiences and contexts. The interviews also enabled the study to explore aspects of the students' application of information skills that were unrevealed during my observation and examination of the programs and relevant materials that would be unexpectedly raised by my interviewees. In this respect, the semi-structured interviews provided "rigor, breadth, complexity, richness and depth" (Denzin \& Lincoln, 2000: p. 5) to the construction of students' application of information skills as experienced and perceived personally by the participants. Among the personal aspects that the study had focused on during the interviews are views, feelings, tacit knowledge, motives, experiences and practices of the participants related to students' application of information skills; which Maxwell (2005), Robson (2002) and Patton (2002) have indicated would be able be accessed via semi-structured interviews.

Data in the study was analyzed using Merriam’s (2009) steps of analysing qualitative data that suggest using the study's research purpose to guide the data analysis process. Using the steps, the study developed bucket, 
open and analytical coding that helps the study to construct a meaningful "classification system" (Merriam, 2009: 180) for personal contexts of students' learning and application of information skills. The classification system indicated patterns and regularities of major themes that appeared frequently across sources and cases. Additionally the study employed Nvivo computer program to organize the data and the developed coding for easy storage and retrieval.

\section{Research Findings}

The major findings of the study showed students' personal learning orientations and goals underpin students' application of information skills in the university learning.

\subsection{Personal Learning Orientations}

As discussed below, the study found that students with personal learning orientation that are in line with the pillars of university learning-independent learning, learning beyond classrooms, dialogic learning, and scholarly learning—use information skills across their classroom learning.

\subsubsection{Independent Learning}

The study showed that students applied information skills when they changed their learning orientation from teacher-centred learning into student-centred learning. An undergraduate student, Cheng took a considerable time to change his personal learning orientation in the university, resulting to non-employment of information skills and non-performance in his first year of study. However, in order to attain good grades in his university study, he gradually changed his expectation of teachers as the ultimate sources of knowledge to facilitators of the knowledge construction. Familiar with the spoon-fed learning approach experienced during his school days, Cheng considered that a transition from school to university learning was not an easy task and requires time for students to undertake. Following his new learning orientation, Chan used information skills in his attempt to search, read, and use information from multiple sources in order to construct his personal understanding independently from his lecturers.

Cheng's experience was shared by lecturers (Ana and Onn) and librarians (Azi, Lea, Mia and Sal) who associated university learning with the practice of "lifelong learning"-learning that is underpinning by independent activities of students' searching, using and transforming information from multiple sources into their personal understanding. Similar to Cheng, the teachers and librarians viewed that there was a need for university students to change their learning orientation from "learning from teachers" to "learning with multiple collaborators or sources".

\subsubsection{Learning beyond Classroom}

The study indicated that students used information skills when they changed their learning orientation from classroom learning to learning beyond classroom walls and period. Razak, another undergraduate student remembered that he managed to get good grades in his school days just by giving a full attention to teachers during classrooms' learning. However, Razak experienced in his first year of study that he could not answer his final examination papers when he depended solely on lectures' notes. Accordingly, he learned from the experience to broaden his locus of learning beyond his classrooms. Likewise, a lecturer (Nora) associated university learning with "self-directed" or "self-accessed" learning that required students to search information from multiple sources at their own pace, time and place. Nora's view of university learning supports Razak's new learning orientation that required students to use information skills while searching, reading, analysing and synthesizing information from multiple sources outside their classrooms' period.

\subsubsection{Dialogic Learning}

The study suggested that students used information skills when they changed their orientation from individual learning to dialogic learning. As mentioned by the lecturers (Onn, Sam and Wani), university learning is about students developing, sharing, and reflecting their understanding and the construction of the understanding with classroom teachers and peers, thesis supervisors and examiners, and experts. Following dialogic learning, students gradually discovered that they needed to develop their understanding independently from lecturers, and later could articulate and reflect that understanding with their classroom teachers, peers, and field experts. Such 
learning requirements induced students to search, select, read, organise, and use information from multiple sources in the development and reflection of their understanding. For instance, during out-of-class undergraduate students (Cheng, Razak, Farah and Farid) searched and shared information from multiple sources with their study group members, and examined closely the obtained information before reaching a collective understanding. This similar activity was also employed by postgraduate students ((Jannah, Naim, Nori, and Wina) with their own study group members. Due to the nature of postgraduate classes that required active student interactions, this study found that postgraduate students further discussed, argued and reflected their understanding with their classroom teachers and peers during classroom learning. On the contrary, undergraduate students often discussed and reflected their collective/group understanding with lecturers outside their classrooms' period, i.e. during the lecturers' consultation hours.

However, Razak, an undergraduate student observed that some of his classroom peers preferred to hoard information in order to elevate their grades. This learning orientation was refuted by a lecturer, Wani, who said that the orientation might be useful in schools that focused on rote learning; i.e. acquisition of information. Nonetheless, such orientation would hamper students' engagement in dialogic learning; i.e. using information to construct knowledge via constructing, articulating and reflecting personal understanding collaboratively with classroom members.

\subsubsection{Scholarly Learning}

The study also showed that students' learning orientation toward scholarly learning reinforced students’ application of information skills. University teachers (Onn and Sam) viewed that university learning involved "scholarly" learning activities that engaged students in "a process of developing a standardization of knowledge" (Onn). Onn further explained that the activities involved a critical evaluation process in which students' understanding and its construction would be reflected and assessed as sufficient/insufficient "evidence” to confer/ non-confer students' scholarship in university learning. Following scholarly learning orientation, lecturers required their postgraduate students to use information skills to present a critical, recent and informed literature review during their research proposal presentation. Similarly, lecturers required their undergraduate students to use information skills to write and present systematic and scientific research proposals and reports that were acceptable by the students' knowledge discipline community. Following the lecturers' requirement, most students in the study used information skills while completing their classrooms’ assignments.

\subsection{Personal Learning Goals}

The findings also showed that long-term and personal learning goals influenced students' application of information skills across classroom learning. Postgraduate students reported that they used information skills to attain their personal learning goals. For example postgraduate students used information skills across their classroom learning as an attempt to transform themselves from learners into experts within their knowledge discipline (Naim and Joe) and classroom (Nori), and well-informed contributors to the well-being of their families, and local and workplace communities (Jannah and Nori). Additionally, postgraduate students (Jannah, Joe, Nori, Rosli and Wina), and undergraduate students (Cheng, Razak, Fazil, and Feza) used information skills while completing their classroom assignments to attain good grades for their classroom assignments and examination and complete their university study successfully. Razak and Cheng also shared information and its sources that they had accessed with their study group members in order to develop a sufficient understanding about their classroom topics, necessary for them to do well in their mid-term and final examinations.

The data analysis indicated that short-term goals - attaining good grades for classroom learning and university graduation-provided a sufficient intrinsic motivation for students to use information skills across their classroom learning. The lecturers supported the notion that instant rewards were essential to engage students in searching, reading, and using information from multiple sources. A university teacher, Ana, graded every learning artefact that her students developed during their participation in classroom learning because she believed that "without the grades", students would not "give their best” in completing the activity. Similarly, another university teacher (Sam) motivated his students to read their course reading materials by informing them that the materials would be included in their "mid-semester examination questions". Sam commented that his strategy worked well with his undergraduate and postgraduate research methods classes.

Moreover, the study suggested that students with relatively long-term personal goals-becoming experts, 
members and contributors in knowledge discipline, classroom, families, and local and workplace communities-chose to use every component of information skills in completing their classroom assignments. On the contrary, students with relatively short-term goals tend to skip certain components of information skills. For example, instead of articulating their understanding in their classroom assignments, second year undergraduate students (Amy, Kay and Kam) copied pieces of writing from personal blogs and used them in their classroom assignments to obtain a better grade for the assignments. Similarly, a final year social science master student (Wina) chose to engage in a project paper over a thesis because the project paper did not require her to articulate, defend, and reflect her understanding sufficiently to internal examiners thus enabling her to graduate from the university relatively sooner. Accordingly, the study highlighted that relatively short-term personal learning goals were only sufficient to engage students in lower levels of information skills, i.e. searching and retrieving information from multiple sources. On the other hand, the study found that it was relatively long-term learning personal goals that were able to sustain students' usage of lower and higher levels of information skills—searching, retrieving, reading, analysing and synthesizing the information, and developing, articulating, and reflecting their understanding - across their classroom learning.

\section{Discussion}

The study indicated that personal learning orientations and goals played a significant role in differentiating university students' application of information skills across their classroom learning. The learning orientations and goals influenced students' application of information skills and sustain active and reciprocal engagement between students and various collaborators of learning-classroom teachers and peers, librarians, knowledge experts, and members of various communities where the students belonged to. Fitzgerald (2005) explained that the way students viewed knowledge as either absolute or fluid would influence students' ways of searching information sources and determining the credibility of information taken from those sources. The findings were also supported by literature that found students' assumption about nature of knowledge and sources of knowledge (Badger \& Roberts, 2005; Bruce, Edwards, \& Lupton, 2006; Bruce, 2005; Gorman \& Dorner, 2006; Grassian \& Kaplowitz, 2001) and academic self-concepts (Brown, 2005) influenced students' approaches towards information-related behaviours and thinking. Moreover, this study indicated that university students with relatively short-term learning goals used online sources without any effort to determine the credibility of these sources because these sources were easily accessible to students. Similar findings were advocated by Jamali (2008) who discovered that higher education students assumed high value of online information sources over other sources based on the level of the sources' accessibility. Such findings may explain why most students in higher education prefer online information sources over other types of sources.

\section{Conclusion}

The study indicated that undergraduate students needed to shift their learning orientations from seeing lecturers as the source of knowledge into regarding lecturers as facilitators of learning, and from seeing teachers as the managers of learning into seeing themselves as autonomous learners who manage their own learning. Unfortunately, the study found that some undergraduate students took almost one whole semester or more before shifting their learning orientations and strategies; enduring a stressful learning experience and low academic achievement in the first semester of their study. The study suggested that the shifting of the learning orientations empowered the undergraduate students to apply information skills across their classroom learning and experienced better engagement in university learning. Accordingly, there is a need for higher education institutions to design and develop special programs to explicitly expose fresh university students to pillars of higher learning and multiple learning strategies that students can use to better engage in university learning during students' orientation weeks. The implementation of such programs could help students, particularly fresh undergraduate students, to re-align their personal learning orientations from school to university learning early in their university life, and thus help them to use information skills and perform better in their study.

The findings also revealed that students with relatively short-term learning goals tend to skip certain components of information skills while completing their classroom assignments, particularly in the area of accessing valid and reliable information sources, and developing, articulating and reflecting personal understanding. Since this area is essential in knowledge building process in higher learning, there is a need for higher education institutions to run dedicated programs to train students to use multiple strategies to search and evaluate online infor- 
mation sources, and to develop, articulate and reflect personal understanding. Although most universities offer information skills programs to students, such programs only focus on searching, accessing and retrieving information from multiple sources. Hence, there is a big gap on how to expose students to the process and train students to use multiple strategies for developing, articulating and reflecting personal understanding, which can be filled by the dedicated programs. While some argued that developing, articulating and reflecting personal understanding were generic skills that students could acquire during classroom learning, the study showed that without basic knowledge and skills on how to develop, articulate and reflect personal understanding, students with relatively short term learning goals skipped this process altogether in their learning process. Moreover, in searching for personal students' academic excellence, higher educational institutions must also connect students to multiple communities that students are and will belong to. Such efforts would help students' development of social identity which was closely related to students' development of relatively long term personal learning goals. As highlighted by the study, the long term learning goals sustain students' usage of information skills in the knowledge building process in university learning; and thus transforming university students to knowledge creators and innovators.

Finally, although the study revealed that personal learning orientations and goals played a significant role in differentiating university students' application of information skills across their classroom learning, more empirical and quantitative studies were needed to support and quantify the nature of relationship between these variables in higher education settings. Such studies would advance and improve the understanding and practice of students' application of information skills in higher education, and thus helping students to better engage in knowledge building process in higher learning.

\section{References}

Abdullah, S., Ahmad Kassim, N., Mohd Saad, M. S., Tarmuchi, N. R., \& Aripin, R. (2006). Developing Information Literacy Measures for Higher Education. Paper Presented at the Asia-Pacific Conference on Library \& Information Education \& Practice 2006 (A-LIEP 2006), Singapore, 3-6 April 2006, 219-228. http://dlist.sir.arizona.edu/1384/01/31.Szarina_Abdullah_pp219-228_.pdf

Badger, J., \& Roberts, S. (2005). Exporting E-Literacy Education. Journal of eLiteracy, 2, 27-41. http://www.jelit.org/54/01/JeLit_Paper_6.pdf

Bawden, D. (2001). Information and Digital Literacies: A Review of Concepts. Journal of Documentation, 52, 218-259. http://dx.doi.org/10.1108/EUM0000000007083

Boon, S., Johnston, B., \& Webber, S. (2007). A Phenomenographic Study of English Faculty’s Conceptions of Information Literacy. Journal of Documentation, 63, 204-228. http://dx.doi.org/10.1108/00220410710737187

Bruce, C. (1997). The Seven Faces of Information Literacy. Adelaide, SA: Auslib Press.

Bruce, C., Edwards, S., \& Lupton, M. (2006). Six Frames for Information Literacy Education: A Conceptual Framework for Interpreting the Relationships between Theory and Practice. e-Journal of Innovation in Teaching And Learning in Information and Computer Sciences, 5, 18 p.

http://www98.griffith.edu.au/dspace/bitstream/handle/10072/14028/36236.pdf?sequence=1 http://dx.doi.org/10.11120/ital.2006.05010002

Bruce, H. (2005). Personal, Anticipated Information Need. Information Research, 10, 16 p. http://informationr.net/ir/10-3/paper232.html

Bundy, A. (Ed.). (2004). Australian and New Zealand Information Literacy Framework: Principles, Standards and Practice (2nd ed.). Adelaide, SA: Australian and New Zealand Institute for Information Literacy.

Catts, R., \& Lau, J. (2008). Towards Information Literacy Indicators: Conceptual Framework Paper. Paris, France: UNESCO.

Chan, S. N. (2003). Making Information Literacy a Compulsory Subject for Undergraduates: The Experience of the University of Malaya. Paper presented at the 69th International Federation of Library Associations. http://dx.doi.org/10.1177/034003520302900411

Chartered Institute of Library and Information Professionals (2012). Information Literacy. 4 p. http://www.cilip.org.uk/sites/default/files/documents/Information\%20literacy\%20skills.pdf

Denzin, N. K., \& Lincoln, Y. S. (2000). Introduction: The Discipline and Practice of Qualitative Research. In N. K. Denzin, \& Y. S. Lincoln (Eds.), Handbook of Qualitative Research (2nd ed., pp. 1-34). Thousand Oaks, CA: Sage Publications.

Doyle, C. S. (1992). Development of a Model of Information Literacy Outcomes Measures within National Education Goals of 1990. Unpublished Doctoral Dissertation, Flagstaff, AZ: Northern Arizona University.

Economic Planning Unit (2001). Eighth Malaysian Plan 2001-2005. Putrajaya: Economic Planning Unit, Prime Minister’s 
Department, Malaysia.

Edzan, N. N. (2007). Tracing Information Literacy of Computer Science Undergraduates: A Content Analysis of Students' Academic Exercise. Malaysian Journal of Library \& Information Science, 12, 97-109.

Edzan, N. N., \& Mohd Saad, M. S. (2005). NILA: A National Information Literacy Agenda for Malaysia. Malaysian Journal of Library \& Information Science, 10, 91-103.

Fitzgerald, M. A. (1999). Evaluating Information: An Information Literacy Challenge. School Library Media Research, 2, 123. http://www.ala.org/ala/mgrps/divs/aasl/aaslpubsandjournals/slmrb/slmrcontents/volume21999/vol2fitzgerald.cfm

Gillham, B. (2000). Case Study Research Methods. London: Continuum.

Gorman, G. E., \& Dorner, D. G. (2006). Information Literacy Education in Asian Developing Countries: Cultural Factors in Affecting Curriculum Development and Programme Delivery. Proceedings of the World Library and Information Congress: 72nd IFLA General Conference and Council, Seoul, 20-24 August 2006, 1-19.

http://www.ifla.org/IV/ifla72/papers/082-Gorman_Dorner-en.pdf

Grassian, E. S., \& Kaplowitz, J. R. (2001). Information Literacy Instruction: Theory and Practice. New York: Neal-Schuman Publishers.

Hepworth, M., \& Wema, E. (2006). The Design and Implementation of an Information Literacy Training Course That Integrated Information and Library Science Conceptions of Information Literacy, Educational Theory and Information Behaviour Research: A Tanzanian Pilot Study. Innovation in Teaching and Learning in Information and Computer Sciences, 5, 1-23. https://www.heacademy.ac.uk/sites/default/files/ital.5.1e.pdf http://dx.doi.org/10.11120/ital.2006.05010005

Herring, J. E. (1996). Teaching Information Skills in Schools. London: Library Association Publishing.

Irving, A. (1985). Study and Information Skills across the Curriculum. London: Heinemann Educational Books.

Jamali, H. R. (2008). What Is Not Available Online Is Not Worth Reading? Webology, 5, 1-5.

Julien, H., \& Boon, S. (2002). From the Front Line: Information Literacy Instruction in Canadian Academic Libraries. Reference Services Review, 30, 143-149. http://dx.doi.org/10.1108/00907320210428697

Karim, A. A., Din, R. \& Othman, K. (2004). The Use of Information Literacy Skill among Science Teacher Trainees in Malaysia. In R. Ferdig, C. Crawford, R. Carlsen, N. Davis, J. Price, R. Weber \& D. Willis (Eds.), Proceedings of Society for Information Technology \& Teacher Education International Conference 2004 (3137-3142). Chesapeake, VA: Association for the Advancement of Computing in Education (AACE).

Karim, A. A., Shah, P. M., Ahmad, M. \& Lubis, M. A. (2014). Developing Information Skills Test for Malaysian Youth Students Using Rasch Analysis. International Education Studies, 7, 112-122. http://www.ccsenet.org/journal/index.php/ies/article/view/43607/23802

Kerns, S. C. (2002). Information Literacy Instruction: Theory and Practice: A Review. Journal of the Medical Library Association, 90, 351. http://www.ncbi.nlm.nih.gov/pmc/articles/PMC116414/

Kilic-Cakmak, E. (2010). Learning Strategies and Motivational Factors Predicting Information Literacy Self-Efficacy of ELearners. Australasian Journal of Educational Technology, 26, 192-208.

Lantz, A., \& Brage, C. (2006). Towards a Learning Society-Exploring the Challenge of Applied Information Literacy through Reality-Based Scenarios. Innovation in Teaching and Learning Information and Computer Science, 5, 1-15.

https://www.heacademy.ac.uk/sites/default/files/ital.5.1c.pdf http://dx.doi.org/10.11120/ital.2006.05010003

Lupton, M. (2003). Researching an Essay: Undergraduates’ Way of Experiencing Information Literacy. Unpublished Master's Thesis, Canberra: Division of Communication and Education, University of Canberra.

Malaysian Qualifications Agency (2007). Malaysian Qualifications Framework: Point of Reference and Joint Understanding of Higher Education Qualifications in Malaysia. http://cgs.unimap.edu.my/images/pdf/MQF.pdf

Marland, M. (Ed.) (1981). Information Skills in the Secondary Curriculum. London: Methuen Educational.

Maxwell, J. A. (2005). Qualitative Research Design: An Interactive Approach. Thousand Oaks, CA: Sage Publications.

Maybee, C. (2007). Understanding Our Student Learners: A Phenomenographic Study Revealing the Ways That Undergraduate Women at Mills College Understand Using Information. Reference Services Review, 35, 452-462. http://dx.doi.org/10.1108/00907320710774319

Ministry of Education Malaysia (2015). Executive Summary: Malaysia Education Blueprint 2015-2025 (Higher Education). Putrajaya: Ministry of Education Malaysia.

http://www.moe.gov.my/cms/upload_files/files/4_\%20Executive\%20Summary\%20PPPM\%202015-2025.pdf

Mohd Saad, M. S., \& Awang Ngah, Z. (2002). Information Literacy Programmes in Malaysian Public Universities: An Observation. Proceedings of the 68th International Federation of Library Associations and Institution Annual Council and 
General Conference, Glasgow, 18-24 August 2002, 1-12. http://www.ifla.org/IV/ifla68/papers/142-098e.pdf

Neely, T. Y. (2000). Aspects of Information Literacy: A Sociological and Psychological Study. Unpublished Doctoral Dissertation, Pittsburgh, PA: University of Pittsburgh.

Patton, M. Q. (2002). Qualitative Research \& Evaluation Methods (3rd ed.). Thousand Oaks, CA: Sage Publications.

Robson, C. (2002). Real World Research: A Resource for Social Scientists and Practitioner-Researchers (2nd ed.). Oxford: Blackwell Publishers Ltd.

Silverman, D. (2006). Interpreting Qualitative Data: Methods for Analyzing Talk, Text and Interaction. Los Angeles, CA: Sage Publications. 